Religious freedom and cultural asymmetry: Some pitfalls of secularism Jakob De Roover

Department of Comparative Science of Cultures, Ghent University, Ghent, Belgium

Apotheekstraat 5, 9000 Ghent, Belgium; Jakob.Deroover@UGent.be 


\section{Religious freedom and cultural asymmetry: Some pitfalls of secularism}

Both in post-Independence India and in contemporary Europe, the problems caused by state interference in religion and tradition are most visible in legal disputes and court decisions. In recent years, the European Court of Human Rights, the Supreme Court of India, and lower-level courts in both parts of the world have had to decide on several major cases: from disputes concerning the wearing of the burqa and hijab in public spaces, through questions about the incompatibility between the right to religious freedom and the fixing of crucifixes on the walls of state school classrooms, to conflicts about government control of the management and practices of temples.

Europe, India, and the Limits of Secularism (2015) addresses the theme of legal disputes concerning secularism and religious freedom only tangentially: it briefly looks at claims made by Indian judges about 'Hinduism' and examines one European case, that of Lautsi v. Italy, in some detail. Still, it is not a coincidence that two contributors to this colloquium point to relevant court decisions and note how certain issues at the heart of my book play out in the domain of law. Prakash Shah discusses a British case that involved the question whether the wearing of the Kara (a type of steel bracelet) is a requirement of the Sikh religion, a practice of exceptional importance to the claimant's religion, or neither. Rajalakshmi Nadadur Kannan mentions the important Sabarimala case. Here, the Supreme Court of India decided about the 'constitutionality' of a traditional practice in the temple of the deity Ayyappa in Sabarimala, a major pilgrimage center located in the South-Indian state of Kerala. The practice stipulates that women between 10 and 50 are not allowed to enter the temple. In his decision of 28 September 2018, the Chief Justice of India claimed that this 'exclusionary' practice is neither an essential nor an integral part of Hindu religion and is therefore not protected by the constitutional right to freedom of religion $(\$ 144) .{ }^{1}$ The court decision caused 
uproar in Kerala and beyond, also among women devotees of Ayyappa; as a consequence, 48 review petitions were submitted to the Supreme Court and the verdict is currently under review.

Both cases have in common that secular courts of law ended up deciding how significant a specific practice is to (the followers of) a religion. Shah notes that the case about the Sikh Kara instantiates a process whereby a specific cluster of concepts begins to give shape to a legal dispute concerning a traditional practice: the cluster consisting of terms such as 'religion', 'faith', 'the secular', 'religious symbol', 'religious belief', 'requirement of a religion'... Indeed, along with this cluster of terms comes a conceptual logic that allows, or even compels, judges to frame the questions in a particular way: Is the practice a compulsory requirement of a religion or only a practice considered important by some of its followers? Or to turn to the Indian courts: Is the supervision of a temple and its rituals an essential part of religion or a set of secular activities that happen to be associated with religious practice?

This type of question may seem inevitable when judges are called on to decide whether legislation infringes upon the religious freedom of a citizen or if the compulsory character of a religious practice warrants exemptions from generally applicable rules. Yet, it brings in its wake a string of problems that we are often unaware of today. Several authors have noted that disputes about religion lead courts into 'talking theology' (Heehs 2013; Sullivan 2018). But a more basic predicament come into being when this conceptual cluster - the cluster consisting of terms such as 'religion', 'the religious', 'the secular', 'faith', etc.—enters the discourse of judges and legislators. It not only determines how facts and questions are framed but also puts implicit limits on what can count as a plausible outcome or decision. For instance, once a dispute is approached as a matter of finding out if a traditional practice is a 
'compulsory requirement' or 'essential part' of a 'religion', the range of potential answers is restricted. Thus, the usage of these terms gives rise to certain constraints on the reasoning about issues of tradition and religion.

Naturally, many clusters of terms similarly constrain and shape our reasoning as human beings. So, what is the predicament all about? It arises because the patterns of reasoning about religion, religious freedom, and the secular state are dependent on specific 'conditions of intelligibility': a set of background ideas and attitudes, which emerged from long-term developments in the western-Christian world and which are required to adequately make sense of this cluster of terms. Where these conditions are absent, reasoning that draws on these terms will run into problems of coherence, clarity, reference, reasonableness, and unanticipated implication (see De Roover, Balagangadhara and Claerhout 2011; Claerhout 2014).

The task at hand is not that of 'deconstructing' terms such as 'the religious' and 'the secular', tracing their 'genealogy', arguing that these are 'colonial categories', and then asking, 'now what?' (Kannan 2019). This collection of clichés has long exhausted its theoretical productivity, if it ever had any. ${ }^{2}$ Rather, we have to explicate and excavate the background framework implicit in the usage of concepts like 'religious freedom', 'the secular', 'faith', etc. That is, we should find out how such concepts presuppose other clusters of ideas that often remain invisible, yet shape the reasoning of judges, politicians, and intellectuals. To do so, we need to examine the emergence of the ideas and institutions of liberal democracy and their ties to larger conceptual developments in western-Christian culture. Only after taking these steps, can we identify how and why the reasoning that draws upon these terms goes haywire, when it is exported to non-western cultures and societies. Then we can also begin to understand 
how and why it leads to legal and political decisions that intrude upon (and often harm) the traditions of people in different parts of the world.

\section{The essentials of religion}

The Sabarimala case offers an occasion to clarify some of the points made in my book. The decision by the former Chief Justice of India, Dipak Misra, illustrates the difficulties that result from introducing the conceptual vocabulary of 'religion' into Indian law and politics. ${ }^{3}$ Consider one of its many problems. Among the questions addressed by Justice Misra is that of determining whether the Sabarimala temple's practice of refusing entry to women aged between 10 and 50 is an 'essential practice of Hindu religion'. If this were the case, then the devotees could claim the protection of the Supreme Court's 'doctrine of essential practices', which stipulates that only practices essential to a religion are protected by the constitutional right to "freely profess, practise and propagate religion" (Article 25 of the Constitution of India, 1950).

In his judgment, Justice Misra seeks to elucidate what is meant by "an essential part or practices of a religion" (§121). In the important Shirur Mutt case of 1951, the Supreme Court decided that "what constitutes the essential part of a religion is primarily to be ascertained with reference to the doctrines of that religion itself” $(\S 114)$. As several scholars noted, this maxim proved inadequate: there are no doctrines available that identify the essential parts of 'Hindu religion', so this approach created the space for judges to decide what is essential to this 'religion', intervene in the 'non-essential' parts, and ban or modify practices which they consider 'superstitious' or 'backward'. In other words, the scope for state interference into traditional institutions and practices expanded, now with the backing of the Supreme Court (Derrett 1996: 447; Sen 2019). In the 1960s, the then chief justice of India, P. B. Gajendragadkar, concluded that even purely secular practices in India "are clothed with a religious form" and other practices 
"though religious may have sprung from merely superstitious beliefs and may in that sense be extraneous and unessential accretions to religion itself." According to the court's doctrine of essential practices, then, the state should be able to legislate about all such practices that are not 'essential' parts of a religion but unessential accretions.

But how could a judge ever determine what is an extraneous and unessential accretion, which arose from superstitious beliefs, as opposed to an essential practice of a religion? To resolve this issue, Justice Misra refers to other authorities and consults a Supreme Court judgment from 2004:

Essential part of a religion means the core beliefs upon which a religion is founded. Essential practice means those practices that are fundamental to follow a religious belief. It is upon the cornerstone of essential parts or practices the superstructure of religion is built. Without which, a religion will be no religion. Test to determine whether a part or practice is essential to the religion is - to find out whether the nature of religion will be changed without that part or practice [sic]. If the taking away of that part or practice could result in a fundamental change in the character of that religion or in its belief, then such part could be treated as an essential or integral part. There cannot be additions or subtractions to such part. Because it is the very essence of that religion and alterations will change its fundamental character. It is such permanent essential parts is what is protected by the Constitution [sic]. Nobody can say that essential part or practice of one's religion has changed from a particular date or by an event. Such alterable parts or practices are definitely not the 'core' of religion where the belief is based and religion is founded upon. It could only be treated as mere embellishments to the nonessential part or practices. $(\S 121)^{5}$

Justice Misra then goes on to determine whether the practice of excluding women of a certain age from the Sabarimala temple is "a doctrine of Hindu religion or a practice that could be regarded as an essential part of the Hindu religion and whether the nature of Hindu religion would be altered without the said exclusionary practice." The answer, in his considered opinion, is "in the firm negative." In fact, according to him, it is an 
essential part of 'Hindu religion' to allow Hindu women into temples to offer their prayers to the deity. At this point, Misra refers to the need for scriptural evidence: "In the absence of any scriptural or textual evidence, we cannot accord to the exclusionary practice followed at the Sabarimala temple the status of an essential practice of Hindu religion" (§122). However, he does not clarify what the 'scriptures' should provide evidence for or how this evidence would lead to a different decision.

One cannot imagine, Justice Misra goes on to write, that the nature of Hindu religion would be fundamentally altered in any manner by prohibiting this practice: "Therefore, the exclusionary practice... is neither an essential nor an integral part of the Hindu religion without which Hindu religion, of which the devotees of Lord Ayyappa are followers, will not survive" $(\$ 123)$. Here, the judge is again drawing upon other Supreme Court rulings. In a 2016 decision, for instance, the court argued that the doctrine of essential practices compels the judges to take up the "delicate and unenviable task of identifying essential religious beliefs and practices, sans which the religion itself does not survive." ${ }^{6}$ In his report, the Amicus Curiae appointed in the Sabarimala case, Senior Advocate Raju Ramchandran, also submitted "that in order to claim protection of the doctrine of essential religious practices, the practice to exclude women from entry to the Sabarimala temple must be shown by the respondents to be so fundamental to the religious belief without which the religion will not survive" (§75). Consequently, if the respondents fail to show that their religion cannot survive without this practice, it is not essential to that religion and deserves no protection under the constitutional right to religious freedom.

To leave no doubt as to the intent of his judgment, the Chief Justice repeatedly insists that nobody can say that an essential part or practice of one's religion "has changed from a particular date or by an event," since such alterable parts or practices 
cannot be the 'core' upon which this religion is founded. These alterable practices should be treated "as mere embellishment to the non-essential part or practices." In other words: "There has to be unhindered continuity in a practice for it to attain the status of essential practice" $(\S 124-5)$. Since it is clear that the disputed practice of the Sabarimala Ayyappa temple was introduced at some particular point of time, it could never count as an essential practice.

These passages in Justice Misra's judgment look peculiar. Practices and doctrines considered central by religions have often changed over the centuries; each of these changes happened at a particular point in time or by some event. For RomanCatholicism, the spiritual status of the priesthood is essential, as is the institutional structure of the Church and the supreme authority of the pope, even though the institution crystallized in this form during and after the eleventh-century papal reform. In contrast, Protestants consider the Roman-Catholic clergy and many of its rites and doctrines as false additions to religion. In post-Reformation Europe, the Protestant confessions created their own creeds, church laws, and confessions of faith, and presented these as fundamentals of religion. They then accused each other of having added human inventions to Christian religion. Each confession argued that its 'essentials' reflect the original and unchanged divine revelation, the pure religion of the Bible, while the others had added things created by human beings at some point of time. This was (and is) also a conflict about distinguishing the 'unchangeable' fundamentals of religion from those things that have been and can be altered. How can a judge take a position in any such debate? Can he identify what has 'truly' been altered as opposed to things that may appear to be alterations but are actually a return to the original and pure religion? Similar questions can be raised about core practices and beliefs of Islam and Judaism. For Justice Misra, however, it is clear that all 'alterable' doctrines and 
practices — which changed at a particular point in time because of certain eventscannot constitute the essential parts of a religion. Instead, they are 'superstitious accretions' and 'mere embellishments' to 'the non-essential parts' of a religion. Therefore, the state should be welcome to restrict or regulate such practices by legislative means.

Other elements of the Indian Supreme Court's doctrine of essential practices are equally confusing. To find out what is essential to a religion, judges should determine which beliefs and practices are necessary to its survival; the removal of these beliefs and practices would fundamentally alter the nature of the religion in question. Without these, "a religion will be no religion," as the court puts it. Here, Misra and his colleagues write as though they are providing a practical or empirical 'test' to identify the essentials of a religion. Remove these essentials and the religion will wither away. Still, it is difficult to see how this type of 'test' would work. Courts of law are not in a position to undertake experiments such as removing a practice from a religion and examining what happens as a consequence. As a thought experiment, the exercise is also difficult to execute: how can judges predict whether a religion would survive or die, if some part is removed from it? ${ }^{7}$

To sum up, as several authors have noted, the apex court of India produces legal doctrines and decisions about religion and religious freedom that appear unreasonable and sometimes bizarre (Derrett 1996; Dhavan and Nariman 2000; Heehs 2013; Sen 2019). Now, the challenge is to make sense of this state of affairs, without taking resort to ad hoc explanations. We need to figure out which difficulties the Indian courts are facing when they have to decide about disputes related to 'religion'. Let me briefly review some potential routes for explaining this state of affairs. 
The first route starts from the claim that Indian judges are simply confronting typical problems of the liberal-democratic secular state and its relation to religion. Thus, Kannan (2019) suggests that cases like that of the Sabarimala temple revolve around the question "how historical practices with supposed justifications from religious traditions intersect with civil rights." In such cases, she says, Indian judges face the difficult issue of having to determine "when laws or court rulings [can] intervene in a private sphere (or faith), and when someone's faith or spiritual practices interfere with the public sphere." Indeed, deciding when the state should and should not intervene in the sphere of religion is a general normative question of liberal-democratic political thought. While tackling this question, judges in western jurisdictions also determine the significance of certain practices to a religion and decide whether policies affecting such practices constitute violations of the right to free exercise. Hence, one might conclude, Indian courts are dealing with difficulties similar to those faced by the judiciary of any liberal secular state.

Does this conclusion throw light on the modus operandi of the Indian judges? Generally, courts in the western world go about differently than Indian courts do with the question of determining what is religious. They consult the claimants, relevant religious authorities, and academic experts who have studied the religion in question. This takes the form of a process where judges usually aim to play as minimal a role as possible in determining whether something is religion and what are compulsory requirements of a religion. This is not to deny that western courts also face disputes about defining 'religion', which cause conflicts in interpreting the right to religious freedom (Greenawalt 2006: 124-56). Moreover, when courts draw on clerical authorities and religious experts to determine if some practice is central to a religion, they inevitably privilege the understanding held by such parties. And it also happens 
that an American judge devises his own "quite idiosyncratic test for determining what counts as religion" (Sullivan 2018: xxi).

Still, the difficulties faced by Indian courts appear to be of a different order than those in the West. To see this, we only have to imagine that similar legal decisions would occur in one of the secular states of Western Europe or North America. If courts of law in some such country began to decide as a matter of legal doctrine which elements of a religion are necessary to its survival or only extraneous and unessential accretions springing from superstitious beliefs, this would be met with disbelief. If a judge were to rule that all 'alterable' practices and doctrines (which have changed over time) are only 'embellishments' to the unessential parts of religion and therefore do not deserve the protection of the right to religious freedom, his decision would cause bewilderment among his fellow magistrates and legal scholars.

There is a second route for explaining the issues raised by the so-called doctrine of essential practices. Critical authors suggest that the Supreme Court of India enters the domain of theology and religious authority, when it decides what is essential and nonessential to a religion. Since judges are neither qualified nor trained to do so, they begin to interfere in religion in incoherent, arbitrary, and often intrusive ways. In 1968, J. Duncan M. Derrett (1996: 447) already noted that the judges "discard as non-essentials anything which is not proved to their satisfaction - and they are not religious leaders or in any relevant fashion qualified in such matters - to be essential, with the result that it would have no constitutional protection.” Rajeev Dhavan and Fali Nariman (2000: 259) put things more sharply:

With a power greater than that of a high priest, maulvi or dharmashastri, judges have virtually assumed the theological authority to determine which tenets of a faith are 'essential' to any faith and emphatically underscored their constitutional power to strike down those essential tenets of a faith that conflict with the 
dispensation of the Constitution. Few religious pontiffs possess this kind of power and authority.

"The most striking aspect of the essential practices doctrine," Ronojoy Sen (2019: 92) argues, "is the attempt by the Court to fashion religion in the way a modernist state would like it to be, rather than accept religion as represented by its practitioners." Such critical remarks have also reached the Indian courts. For instance, in his concurring judgment in the Sabarimala case, Supreme Court Justice D. Y. Chandrachud notes that the compulsions of the doctrine of essential practices "have led the court to don a theological mantle" or "a religious mantle." 8 Often, these observations are accompanied by a historical account: many citizens in the post-Independence era felt that 'Hinduism' was in need of reform, given irrational and unjust practices such as untouchability, but its many traditions did not share any central authority which could take up the desired reform; consequently, the Indian state and its courts of law acquired this reformatory role after being asked or authorized by Hindus to do so (e.g. Mehta 2005).

These statements about the Supreme Court's assuming of the role of 'theological authority' miss a crucial dimension of the situation. The judges are not donning a theological mantle or taking up religious reform, but merely using terminology which creates the impression that they are 'talking theology' or 'refashioning religion'. In fact, they have picked up a conceptual vocabulary without appearing to understand the basic terms, interconnections, and consequences of their statements. That is, Indian judges habitually use words and phrases such as 'religion', 'secular', 'superstitious beliefs', 'extraneous accretions to religion', and 'essential parts of religion', but they do so in ways that indicate ignorance of the meaning, reference, and implications of these words and phrases. If there is one thing that the relevant Supreme Court decisions prove, it is 
this: the introduction of the conceptual vocabulary of 'religion' into law has resulted in incoherent, inadequate, and sometimes inane reasoning among Indian judges.

A third route might explain away the quality of the Indian court judgments concerning religious freedom by questioning the intellectual capacities and knowledge of the individual judges. But this is a dead-end: the Supreme Court of India's 'doctrine of essential practices' and its body of decisions about the state's relation to 'religion' are the work of generations of judges and legislators. How then could we account for the peculiar type of reasoning that emerges when Indian courts deal with issues of religion?

\section{Religious fundamentals and things indifferent}

A major difficulty has to do with the conceptual foundations underlying dominant ideas of religion, the secular, the state, and religious freedom. When concepts from western political and legal thought migrate to a different cultural setting such as Indian society, their conditions of intelligibility do not travel with them. As a consequence, Indian judges (and other intellectuals) use clusters of English-language terms without having access to the larger structures or clusters of ideas and attitudes within which these terms are embedded. This results in incoherent discourse and language usage that is frequently confounding and occasionally borders on the nonsensical.

Court decisions such as the Sabarimala judgment exemplify this state of affairs. The western-Christian world knows of an age-old tradition of thinking about the 'essentials' necessary to religion, as opposed to things indifferent to religion ('adiaphora', as they were sometimes called in early modern Europe). In fact, distinguishing between things necessary and things indifferent is one of Christianity's central concerns: it is the task of separating that which is revealed and required by the biblical God from human customs and inventions. According to this religion, human 
beings are created to worship God and one's eternal salvation depends on doing so in the right way. Therefore, finding out what is fundamental to divine worship is of supreme importance. In post-Reformation Europe, this concern played a key role in the disputes between competing Christian confessions (Catholics, Lutherans, Calvinists, Anabaptists, etc.), where each confession felt the need to identify its fundamentals and show how these differed from the teachings and practices of other confessions. A recurring theme among Protestants went as follows: true religion is God's revelation of His will to humanity; hence, all things necessary to religion are found in His Word or Scripture; other things, such as the many rites and doctrines of the Roman-Catholic Church, are human fabrications added to religion; when these are falsely presented as necessities of religion, they become 'superstitious accretions' and 'idolatrous impositions'. In post-Reformation Europe, each of the Christian confessions accused its rivals of imposing human additions as though these constituted essential parts of religion.

Early modern theorizing about religious freedom and toleration crystallized in Europe against the background of such conflicts. It frequently drew upon the difference between things necessary and things indifferent to a religion (though it used various terms to refer to this distinction). The right to religious freedom implied that the state should not interfere in those domains of practice considered fundamental by a religion: the things believed to be revealed and required by the Creator. Naturally, the state should strive for impartiality in its decision as to what counts as religious and leave the answer to the different communities as much as possible. This went together with standard ways of identifying the fundamentals of a religion: turning to its scriptures and their orthodox interpretations; consulting its creeds, confessions of faith, and church law; conferring with the relevant authorities of a church or denomination. In matters 
indifferent to religion, however, the state could intervene whenever legislation was needed to curb practices.

To this day, this principle continues to function as a heuristic in western legal and political debates about the right to religious freedom. In fact, it is against this background that the British judge in the case discussed by Shah felt the need to determine whether or not the wearing of the Kara is a requirement of Sikh religion. When western judges raise such issues, they are drawing upon an implicit network of ideas and assumptions concerning the nature of religion. The phrase 'compulsory requirement of religion' relies upon the distinction between things necessary and things indifferent to religion, which in turn presupposes an implicit account of religion as a phenomenon where believers are under the obligation to do and believe certain things (because these are said to be revealed and commanded by God). Therefore, when judges address questions related to religion and religious freedom, they are building on centuries of practice in making this and other distinctions in political, legal, and theological debate. In this sense, the reasoning about the relationship between 'religion' and state relies upon certain conditions of intelligibility.

In western law and politics also, the dependency on this larger background framework sometimes causes difficulties in the reasoning about matters of religion. Complications arise especially when courts in the West have to decide about traditions that fail to fit into the implicit structures of this framework. For instance, most Asian or Native American traditions do not have a structure that allows for making distinctions such as 'the religious' and 'the secular', 'compulsory requirement', 'essential practice' or 'thing indifferent'. However, Indian judges confront a more complex quandary. When they pick up this vocabulary and its phrases from their western colleagues, they 
have no access to the larger background consisting of clusters of ideas and attitudes shaped by centuries of debates and developments within the western world.

The distinction between essentials and non-essentials in religion, or compulsory requirements of a religion versus personal preferences, is not only alien to Indian traditions but also fails to make sense here. For instance, many scholars argue that 'Hinduism' does not refer to a distinct and coherent religion defined by some core or essence, but is "an acceptable abbreviation for a family of culturally related traditions" or "a potpourri of religions, doctrines and attitudes toward life, rites and cults, moral and social norms" (Lipner 2010: 6-7; Michaels 2004: 3-4; see also Doniger 2014: 3-4; Frazier 2011: 2-3). Therefore, when judges aim to identify the essential parts of 'Hinduism' or want to determine if the banning of some practice would fundamentally alter the nature of 'Hindu religion', they inevitably run into a quagmire. How could they ever do so, if the term 'Hinduism' refers to a set of culturally related traditions or a potpourri of doctrines and practices without 'core' or 'essence'?

Under these conditions, it must be impossible to reasonably discuss which practices are essential to 'Hindu religion', which parts are necessary for its survival, and when the fundamental nature of this religion has changed. Yet, this is precisely what Indian judges claim to do. Consequently, they come to decisions that appear both random and irrational. Sometimes, they insist that religious doctrines should be consulted to find out what is essential to a religion: only if it is sanctioned by the religion's scriptures, can a practice or doctrine be an essential part of religion. At other times, they argue that what is considered religious by some religion may in fact consist of 'accretions' inspired by 'superstitious beliefs'; thus, even doctrines and practices rooted in 'scriptures' can be 'embellishments' to the non-essential parts of a religion. Or the judges conclude that any practice or doctrine that has altered over time cannot be 
essential to religion. Court decisions then go on to mingle these claims and approaches. This is what happens when judges adopt a conceptual vocabulary and its terms and phrases, in the absence of the conditions required to make sense of them. The result is the Supreme Court of India's doctrine of essential practices. Rather than protect the right to freedom of religion granted by the Constitution of India, this 'doctrine' has served as a justification for wide-ranging state interference in traditional practices and institutions.

\section{The pitfalls of cultural asymmetry}

In his contribution, Vasileios Syros focuses on another aspect of my book: the issues it raises for the comparative study of political ideas and the future of comparative political theory. Syros suggests that comparative political theory "could certainly play a vital role in helping forge a new conceptual apparatus and armory of analytical tools that will be indispensable in exploring different modes of tackling religious diversity and fostering toleration across different societies." To play this role, he adds, it cannot remain "a merely academic exercise pursued by armchair political theorists" but should be willing "to touch the palm of human society." As I suggest in the book, many Asian societies have accommodated a cultural, religious, and ethnic diversity much greater than that of Europe for centuries; therefore, they must have devised ways of addressing tensions and conflicts related to diversity. Hence, it is plausible that studying their traditions of political thinking would help develop a new conceptual apparatus that goes beyond the currently dominant models of secularism and toleration. But is comparative political theory able to deliver on this promise?

The call for a comparative political theory is inspired by the assessment that this field of study remains 'ethnocentric' and 'parochial' because it assumes that western political thought is universal and largely ignores the political thinking of other cultures 
(Dallmayr 2004 and 2010; Euben 1997; Kapust and Kinsella 2017: 1; Vacano 2015). Rather than assume that only western political thinking can offer adequate solutions to the problems of our time, it intends to approach non-western thinkers and traditions of thought as living sources of knowledge with equal potential to address these problems. Why would we need a comparative political theory at all? Looking at the contemporary state of politics in most Asian and African countries, a skeptic would conclude that there is little to learn there, except how not to give shape to political and legal institutions. Yet, today, the western world appears to be headed for political crisis of a potentially catastrophic scale. More than ever, large sections of the population are alienated from an 'establishment' which they consider to be corrupt and out of touch with the real world. Many citizens feel a need to revolt against these politicians, 'experts' and mainstream media. Along with this discontent, a new type of politician and politics is on the rise across Europe and other parts of the world. The Brexit-debacle has brought to the surface the disintegration of centuries-old institutions into political chaos. And the reporting on the Trump presidency excels in illustrating how shallow and stale political analysis and debate have become in the United States.

One striking aspect of this crisis is our general inability to conceptualize it. Beyond criticism of 'populism', 'demagoguery' and 'post-truth' politics, we do not possess the theoretical language required to make sense of these tendencies and predict their impact on our institutions. In other words, political theory appears to have exhausted its capacity to help reflect on the problems and phenomena of contemporary politics. Now, there is an intriguing parallel here: Asian scholars have often suggested that the conceptual tools of western social and political thought become inadequate when they are used to study non-western societies. In 1993, for instance, Partha 
Chatterjee noted how the richness of historical material in India led to a sense of overwhelming complexity:

...[T]he feeling of unmanageable complexity is, if we care to think of it, nothing other than the result of the inadequacy of the theoretical apparatus with which we work. Those analytical instruments were fashioned primarily out of the process of understanding historical developments in Europe. When those instruments now meet with the resistance of an intractably complex material, the fault surely is not of the Indian material but of the imported instruments. (Chatterjee 1993: 169)

Today, we are discovering that this experience of unmanageable complexity is much wider in scope: the theoretical apparatus of western political thinking fails to conceptualize the 'intractably complex' problems surfacing in western politics, let alone in other parts of the world. Here also, we have to admit that the fault cannot lie with the material studied but must be located in the analytical instruments being used. If this is the case, we should surely look for other instruments and sources. Given the apparent exhaustion of western political thinking, this search for an alternative conceptual apparatus should turn to non-western thinkers and traditions of thought, so as to examine whether these can help reflect on the crises of contemporary politics.

Much like earlier projects such as postcolonial studies, however, comparative political theory faces a peculiar problem. The political and social theorizing of the past centuries has presented institutions and ideas emerging from Europe (liberal democracy, the rule of law, the sciences, gender equality, etc.) as alternatives to the 'traditional' institutions and ideas of non-western societies. Now, 'being an alternative to' is a symmetric relationship: if coffee is an alternative to tea, tea is an alternative to coffee. Still, as S. N. Balagangadhara (2012: 72-3) points out, this symmetry is broken in situations of cultural difference: at a macro-level, the institutions and traditions of thinking from non-western cultures have not been studied as alternatives to those that 
emerged in the West (barring micro-level explorations into, say, mindfulness meditation, management of natural resources, or traditional forms of dispute resolution).

Syros highlights this condition of cultural asymmetry and suggests that the project of comparative political theory may help address it. It should allow us to incorporate conceptual categories from different traditions into contemporary political thought and provide a viable alternative to the liberal model of secularism and toleration. This certainly sounds appealing, but it also threatens to underestimate the hold of cultural asymmetry on our current intellectual world.

Let us agree to look to Asian cultures and thinkers as resources for developing a new generation of ideas about politics. This inquiry will inevitably draw on some framework to conceptualize these as alternatives to the dominant ideas and institutions produced by western theorizing. That is, unless comparative political theory is to become a parochial enterprise built around inaccessible terms from Sanskrit, Pali, or classical Chinese, we need to formulate its alternative ideas in a language accessible to the $21^{\text {st }}$-century world. But the conceptual vocabularies available for doing so are precisely those that emerged from centuries of western theorizing. They produced the entrenched body of descriptions of Asian cultures, translations of their texts, and reflections on their institutions and ideas. That is, almost all of these descriptions, translations, and reflections crystallized against the background of western culture. More importantly, they have largely failed to access Asian traditions as living conceptual resources for our time. How can we then hope to draw a new generation of ideas from Asian thinking about politics, in the absence of an alternative for the background frameworks that have so far prevented us from doing so?

The condition of cultural asymmetry poses challenges that go far beyond simply acknowledging or even celebrating the contributions of non-western thinkers to the 
contemporary world. At its crudest, it presents the encounter between cultures as a competition for civilizational value, where one culture is judged superior to another (or to all others). But cultural asymmetry is a many-colored beast, which appears in subtler hues. These pose major pitfalls for comparative political theory, since they reinforce the grip of cultural asymmetry but often do so under the guise of emancipatory intent.

Consider the current discourse about multiple 'secularisms' or 'secularities'. Scholars suggest that there is no one universal model or meaning of secularism; even the western world knows of multiple forms; hence, we should not take any one model or meaning as the reference point to assess state-religion relations in different countries and regions. Instead, each of the multiple models and meanings of 'secularism' has its own legitimacy, as it emerges from a particular set of historical constellations.

Following this line of reasoning, scholars have characterized Indian secularism in terms of its distinct meaning and form: 'principled distance between religion and state', 'basic symmetry of treatment', 'equal respect for all religions', or an 'ameliorative' model constituted by the attempt to find an equilibrium between religious freedom and social justice (Acevedo 2013; Bhargava 2007; Sen 2005: 294-316; Depaigne 2017: 135-64; Jacobsohn 2003).

The claims about the distinctiveness of Indian secularism lose much of their luster when juxtaposed to the actual situation in contemporary India. Judges hold forth about the true teachings of 'Hinduism', decide which practices are essential to this religion, and enable the state to intervene in a variety of traditional practices and institutions. They also determine that mosques are not an essential part of the practice of Islamic religion, since namaz (prayer) can be offered anywhere. Government bureaucracies are in control of thousands of temples; they not only manage the finances and administration of these traditional institutions, but also supervise the performance 
of rituals and the functioning of pujaris (Berti et al. 2016; Heehs 2013; Presler 1988; Sen 2019). In western secular democracies, parallel situations would be considered violations of the tenets of the secular state and the right to religious freedom. Could they ever count as the distinctive form taken by secularism in India?

Undoubtedly, the secular state has assumed distinct forms in different countries, rooted in the problem situations from which they emerged. But this fact alone does not allow for the conclusion that multiple forms of 'secularism' exist across our globe, each of which has its own historical legitimacy. There are limits to what can count as a secular state that respects the right to religious freedom. Take an analogous argument: "The silencing of political dissent may violate the right to free speech in liberal democracy, but when it happens in China or Latin America, it counts as a distinctive way of expressing the freedom of speech. There is no universal meaning or form of 'free speech' but only multiple 'free speeches', which arise from different historical circumstances." In this analogy, the cultural asymmetry must be obvious: a situation rejected as a blatant infringement of basic principles and rights in western democracies, becomes a distinct way of expressing the same principles and rights simply because it occurs in another culture. Scholars speaking of a distinctively Indian secularism are treading along the same path. Only under this condition of cultural asymmetry could one plausibly view 'state-religion' relations in contemporary India as a distinct form of secularism, which seeks an equilibrium between religious freedom and social justice or principled distance between religion and state.

If it is to retain credibility, comparative political theory cannot lend legitimacy to flawed ideas and political arrangements, simply because they emerge in a nonwestern cultural setting. The project confronts another pitfall, when it turns to the past: that of looking to Asian thinkers and traditions in order to argue that these produced 
ideas akin to modern liberal-democratic ideals, but centuries before European thinkers came up with similar notions. The Emperor Ashoka's notion of Dhamma and Akbar's rule are said to constitute "forms of secularity before secularism" (Bhargava 2013). Similarly, Buddha, the Bhakti traditions, and the Lingayat movement have been fêted because they argued for human equality and against caste discrimination, many a century before the emergence of egalitarianism in Europe. In other words, the merit of past Asian thinkers lies in their capacity to look like the infant John Locke or John Rawls of the East, long before Locke and Rawls were born in the West.

Two questions suffice to reveal the fragility of this approach: Why turn to nonwestern thinkers and traditions, if they merely produced ideas later elaborated in more systematic and sophisticated ways by western thinkers? What is the significance to contemporary political thinking of the fact that some Asian ruler or thinker anticipated modern-day ideals of secularity, equality, democracy, or liberty? Beyond purely historical interest, this approach is but the intellectual equivalent of "we had metallurgy and gunpowder before the West did" or "India already knew of plastic surgery in medieval times." It is a re-packaging of the message of cultural asymmetry: in the past, the best that Indian thinkers could do was anticipate future insights and institutions of western political thought; in the present, the best they can do is imitate these same insights and institutions by building a 'distinctively Indian' copy.

If it travels along these routes, comparative political theory will soon become the intellectual counterpart of "boutique multiculturalism" (Fish 1997). Instead of urban neighborhoods filled with colorful 'ethnic' restaurants, it will produce books and journals, where each chapter or article introduces some exotic author(s) or tradition and proposes that these have 'much to contribute' to our thinking about secularism, tolerance, democracy, freedom, etc. Courses on political thought will expand 'the 
canon' by including obligatory sections on Confucius, Kautilya, Ibn Khaldun, or Gandhi, along with the usual line-up of European and American thinkers. In spite of its intentions, however, this path again threatens to reinforce rather than weaken the hold of cultural asymmetry. The risk is that one considers authors significant because of their cultural origin and then juxtaposes them to a canon of western thinkers, who were selected over centuries allegedly because of the quality and originality of their ideas.

To avoid these pitfalls, comparative political theory must always keep in mind the challenge put forward by its skeptics: it should be able to show how non-western thinkers and traditions of thought have generated insights into politics, which are absent from western political thinking and remain relevant to the twenty-first-century world. To appreciate the urgency of this task, we need only contemplate the contrast between the complexity of the current political crisis in the western world and the conceptual poverty of our reflections on its nature. The sense of unmanageable complexity and chaos in political institutions is evidence of the failure of the currently dominant political-theoretical frameworks.

Asian intellectuals have had a similar experience for many decades now: the conceptual apparatus of the western social sciences failed to make sense of the phenomena they encounter in the societies and politics of the Asian world. At the same time, the institutions left behind by centuries of colonial rule have long looked as chaotic as the British House of Commons and the US presidency do these days. If we wish to discover the reasons behind the massive failure to conceptualize and address the emerging worldwide crisis of political institutions and ideas, examining this experience offers perhaps the most promising starting point. 


\section{References}

Acevedo, Deepa Das. 2013. "Secularism in the Indian Context." Law \& Social Inquiry, 38 (1): 138-167.

Balagangadhara, S. N. 2012. Reconceptualizing India Studies. New Delhi: Oxford University Press.

Berti, Daniela, Gilles Tarabout and Raphael Voix, eds. 2016. Filing Religion: State, Hinduism, and Courts of Law. New Delhi: Oxford University Press.

Bhargava, Rajeev. 2007. "The Distinctiveness of Indian Secularism.” In The Future of Secularism, ed. T. N. Srinivasan. New Delhi: Oxford University Press. Bhargava, Rajeev. 2013. "Forms of Secularity Before Secularism: The Political Morality of Ashoka and Akbar.” In Worlds of Difference, ed. Saïd Amir Arjomand and Elisa Reis. Thousand Oaks: Sage.

Chaitra, M. S. and Ashwini B. Desai. 2019. "Vratabhanga, Paapa and Adharma: Sabarimala and a Case of Justice in India." Pragyata, 14 January 2019.

Dallmayr, Fred. 2004. "Beyond Monologue: For a Comparative Political Theory," Perspectives on Politics 2: 249-57.

Dallmayr, Fred, ed. 2010. Comparative Political Theory: An Introduction. New York: Macmillan.

Depaigne, Vincent. 2017. Legitimacy Gap: Secularism, Religion, and Culture in Comparative Perspective. Oxford: Oxford University Press.

Derrett, J. D. M. [1968]1996. Religion, Law and the State in India. New Delhi: Oxford University Press.

Dhavan, Rajeev and Fali Nariman. 2000. "The Supreme Court and Group Life: Religious Freedom, Minority Groups, and Disadvantaged Communities.” In Supreme but not Infallible: Essays in Honour of the Supreme Court of India, ed. B. N. Kirpal. New Delhi: Oxford University Press.

Doniger, Wendy. 2014. On Hinduism. Oxford and New York: Oxford University Press.

Euben, Roxanne L. 1997. “Comparative Political Theory: An Islamic Fundamentalist Critique of Rationalism.” The Journal of Politics, 59(1), 28-55.

Frazier, Jessica. 2011. "Introduction: New Visions of Hinduism.” In The Continuum Companion to Hindu Studies, ed. J. Frazier. London and New York: Continuum.

Fish, Stanley. 1997. "Boutique Multiculturalism, or Why Liberals Are Incapable of Thinking about Hate Speech." Critical Inquiry, 23(2), 378-395. 
Greenawalt, Kent. 2006. Religion and the Constitution, vol. 1: Free Exercise and Fairness. Princeton: Princeton University Press.

Heehs, Peter. 2013. “'Not a Question of Theology’? Religions, Religious Institutions, and the Courts in India." Comparative Legal History, 1(2), 243-261.

Jacobsohn, Gary J. 2003. The Wheel of Law: India's Secularism in Comparative Constitutional Context. Princeton: Princeton University Press.

Kannan, Rajalakshmi Nadadur. 2019. "Subaltern agency and the problems in the project of decolonization in the study of religion and liberal secularism." Sikh Formations: Religion, Culture, Theory, published online 17 January 2019.

Kapust, Daniel J. and Helen M. Kinsella. 2017. “Introduction: Theory’s Landscapes.” In Comparative Political Theory in Time and Place, eds. Daniel Kapust and Helen M. Kinsella. New York: Palgrave Macmillan.

Lipner, Julius. 2010. Hindus: Their Religious Beliefs and Practices. London and New York: Routledge.

Mehta, Pratap Bhanu. 2005. "Hinduism and Self-Rule.” In World Religions and Democracy, eds. L. Diamond, M. F. Plattner and P. J. Costopoulos. Baltimore and London: The Johns Hopkins University Press.

Michaels, Axel. 2004. Hinduism: Past and Present. Princeton: Princeton University Press.

Presler, Franklin A. 1988. Religion under Bureaucracy: Policy and Administration for Hindu Temples in South India. Cambridge: Cambridge University Press.

Said, Edward. 1978. Orientalism. London: Routledge \& Kegan Paul.

Sen, Amartya. 2005. The Argumentative Indian: Writings on Indian History, Culture and Identity. London: Penguin.

Sen, Ronojoy. 2019. Articles of Faith: Religion, Secularism, and the Indian Supreme Court. Updated edition. New Delhi: Oxford University Press.

Shah, Prakash. 2019. "Secularism's threat to tradition: A reading of Europe, India and the Limits of Secularism." Sikh Formations: Religion, Culture, Theory, published online 11 February 2019.

Sullivan, Winnifred Fallers. 2018. The Impossibility of Religious Freedom. New edition. Princeton and Oxford: Princeton University Press.

Tejani, Shabnum. 2008. Indian Secularism: A Social and Intellectual History, 18901950. Bloomington and Indianapolis: Indiana University Press. 
Vacano, Diego von. 2015. "The Scope of Comparative Political Theory." Annual Review of Political Science, 18: 465-480. 
${ }^{1}$ The references between brackets refer to the numbered paragraphs in Indian Young Lawyers Association v. The State of Kerala, Supreme Court of India, 28 September 2018.

${ }^{2}$ Generally, Kannan confuses between my book's themes and her own concerns about “the problem of decolonization" and "subaltern agency" (even though I do not even use these terms). She lists a series of themes and authors which I should have discussed, according to her: "the field of missionary history," "the representations of Islam, gender and sexuality of the Middle East in Western literature," "representations of Islam and Christianity...in the Middle East," "the intersectionality of economics and politics," "gender and sexuality," and so on. Not discussing these themes, Kannan claims, amounts to "decontextualizing religion and secular from politics and gender" and a failure to specify "whose agency...the book [is] trying to acknowledge." Indeed, I also fail to discuss global warming, identity politics, LGBTQ rights, quantum gravity, and many other matters. Undoubtedly, these are serious flaws. Then again, the book focuses on the emergence of the liberal model of the secular state and religious toleration in early modern Europe and the attempt to introduce this model and its conceptual vocabulary into India. (And it neither seeks to acknowledge nor deny anyone's agency.)

${ }^{3}$ Indian Young Lawyers Association v. The State of Kerala, Supreme Court of India, 28 September 2018.

${ }^{4}$ The Durgah Committee, Ajmer vs Syed Hussain Ali and Others, Supreme Court of India, 17 March 1961; 1961 AIR 1402. For more on justice Gajendragadkar, see chapter 7 in Sen 2019.

${ }^{5}$ The quotation is from a case where the Supreme Court was asked (for the second time) to decide whether the Tandava dance is an essential practice of the 'Ananda Margi faith' or not. See Commissioner of Police \& Ors vs Acharya J. Avadhuta and Anr, 11 March 2004, AIR 2004 SC 2984.

${ }^{6}$ Adi Saiva Sivachariyargal v. Government of Tamil Nadu, AIR 2016 SC 209; emphasis added. 
${ }^{7}$ Anil Rao begins to explore some of these issues concerning the doctrine of essential practice in his Master's thesis, Freedom of Religion and the Supreme Court of India (2018), submitted as a requirement for the degree of Master of Laws at Ghent University, Belgium.

${ }^{8}$ Indian Young Lawyers Association v. The State of Kerala, Supreme Court of India, 28 September 2018. 